\title{
"De aanspraak der Natie" : het koninklijk recht van kamerontbinding en de rol van de kiezer
}

Citation for published version (APA):

van den Berg, J. T. J. (2004). "De aanspraak der Natie" : het koninklijk recht van kamerontbinding en de rol van de kiezer. Maastricht University. https://doi.org/10.26481/spe.20041119jb

Document status and date:

Published: 19/11/2004

DOI:

10.26481/spe.20041119jb

Document Version:

Publisher's PDF, also known as Version of record

\section{Please check the document version of this publication:}

- A submitted manuscript is the version of the article upon submission and before peer-review. There can be important differences between the submitted version and the official published version of record.

People interested in the research are advised to contact the author for the final version of the publication, or visit the DOI to the publisher's website.

- The final author version and the galley proof are versions of the publication after peer review.

- The final published version features the final layout of the paper including the volume, issue and page numbers.

Link to publication

\footnotetext{
General rights rights.

- You may freely distribute the URL identifying the publication in the public portal. please follow below link for the End User Agreement:

www.umlib.nl/taverne-license

Take down policy

If you believe that this document breaches copyright please contact us at:

repository@maastrichtuniversity.nl

providing details and we will investigate your claim.
}

Copyright and moral rights for the publications made accessible in the public portal are retained by the authors and/or other copyright owners and it is a condition of accessing publications that users recognise and abide by the legal requirements associated with these

- Users may download and print one copy of any publication from the public portal for the purpose of private study or research.

- You may not further distribute the material or use it for any profit-making activity or commercial gain

If the publication is distributed under the terms of Article $25 \mathrm{fa}$ of the Dutch Copyright Act, indicated by the "Taverne" license above, 


\section{"De aanspraak der Natie"}

Het koninklijk recht van kamerontbinding en de rol van de kiezer 


\section{Colloton}

Bashontwerp en vealisatie: Unigrophic, Uniwersiteit Maostricht.

Omblog-llustrotie: Foto Dink Donker Curths uit: Dirk Donker Curtius Ministre détat Nérlandais.

Foto FA Hall wit: Aan dexe zilde wan het Binnenhof.

ASBN $90-5681-210-16$

NUR 823

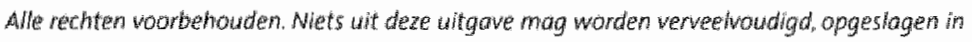
aen gentomatiseerd gegewenswestand of open baar gemaakt, zonder voarafgande schrifte. lifke toestemining von de outicur of uhtgever.

Foto omslag: linils: F A van Hall, minister wan Financiem, $1843-1848$, van Batenlandse Zaken. 185.1856 en oprieuw wan Financiën, 1860-1861. Lid van de Tweede Kame, 1848 (buitengewoon lidl), $1849-1353.1860-1861$. Sinds 1848 Minilster wan stat,

rectrts: D. Donker Curtius, minister wan Justitie, $1848-1349$ en $1859-1856$. Lid van de Tweede Kaner, $1849-1850$. Minister van 5tetlat sedert 1856 


\section{"De aanspraak der Natie" Het koninklijk recht van kamerontbinding en de rol van de kiezer}

Rede

uitgesproken bij de aamvaarding van het ambt van hoogleraar in "het parlementaire stelsel: rechtsnormen en machtsverhoudingen" aan de Universiteit Maastricht,

op vrijdag 19 november 2004

door

Prof. dr. J.Th.J. van den Berg

v 
Mijnheer de Rector Magnificus,

Dames en Heren.

\section{Het goede voorbeeld van 1853}

Floris van Hall en Dirk Donker Curtius hadden in 1853 nog zó zeer het goede voorbeeld gegeven.'

Toen Paus Pius $1 X$ in het voorjaar wan 1853 de bisschoppelijke hiërarchie in de Nederlandse kerkprovincie had hersteld, leidde dat tot een protestantse volksopstand met licht hysterische trekken. Een meer beschaafde uiting daarvan was een petitie aan koning Willem III, waarin werd gevraagd de komst van de bisschoppen naar vermogen tegen te gaan. De petitie, voorzien van 200.000 handtekeningen, werd de koning aangeboden tijdens zijn Jaarlijks bezoek aan de hoofdstad Amsterdam. Over de vraag hoe hij daarop moest reageren was door het kabinetThorbecke advies uitgebracht: de koning zou zich neutralat en formeel moeten opstellen; de nieuwe Grondwet liet immers geen ruimte voor regeringsingrijpen. De koning hield zich niet aan Thorbeckes ardvies, onder andere omdat hij sympathiseerde met de antikatholieke Aprilbeweging. Toen de ministers dat constateerden, dienden zij allen hun ontslag in. Daar had de koning op gerekend. Al vóór de formele ontslagaanvraag had hij gesproken met de Amsterdamse advocaat en oudminister, F.A. van Hall, over de vorming van een nieuw kabinet. Die had zich vervolgens verzekerd van de steun van $D$. Donkel Curtius, de man die in 1848 , als minister van Justitie, de grondwetsvoorstellen door de beide Kamers had weten te loodsen.

De beide heren waren onmiskenbaar liberaal maar geen vrienden van de doctrinaire en lichtelijk rancuneuze Thorbecke. Dus moesten zij rekenen op ernstige weerstand in de Tweede Kamer onder Thorbeckes aanhangers, liberalen en katholleken, die waarschijnlijk een meerderheid tegen Donker en Van Hall in het geweer zouden brengen. Wijselijk verzocht hun kabinet derhalve de koning om de Tweede Kamer te ontbinden, hoewel er strikt genomen nog geen conflict was tussen regering en Tweede Kamer. ${ }^{2}$ De beide heren wilderi het er echter niet op aan laten komen en in de verhitte gemoederen van april 1853 was dat te begrijpen. De aanhangers van Thorbecke en de liberale pers reageerden uiteraard furieus op de kamerontbinding: hun politieke held werd 
immers midden uit zijn grote en verdienstelijke arbeid op Binnenlandse Zaken verwijderd, ofschoon de Kamer hem aldoor had gesteund. Dat er sinds 185 weinig meer uit Thorbeckes handen was gekomen en zijn kabinet als los zand aan elkaar hing, bleef daarbij onbesproken."

Van Hall en Donker besloten daarom het verzoek tot ontbinding van de Tweede Kamer te voorzien van een openbare toelichting. "Daarin gingen zif in op de redenen voor de gewenste ontbinding - vooral rust brengen in het land - maar gaven zij eveneens aan wat hum kabinet met een eventueel kiezersmandaat zou gaan doen. Daarin waren opgenomen: ongewijzigd behoud van ce Grondwet valm 1848 (ter geruststelling wan liberale en katholieke kiezers), een wet op de kerkgenootschappen (ter geruststelling van de opstandige protestanten) en mogelijk wijzigingen in de Germeentewet en Provinciewet. Belangrijk hieraan: de samenstelling van een nieuw kabinet en de formulering van zijn politieke programma gingen vooraf aan de ontbinding van de Tweede Kamer. Voor de kiezer was dus duidellijk waarvoor of waartegen hij zich kon uitspreken. In de woorden wan Van Hall en Donker: de Natie "heeft er aanspraak op. te weten, wat zij van een nieuw opgetreden bestuur mag wachten".

Dat is nu wat ik hun "goede voorbeeld" noem. Bij ontbinding van de Tweede Kamer moet duidelijk zijn woor welk regeringsbeleid kan worden gekozen. Maar, theeft goed voorbeeld hier goed doen volgem? Die vraag zal ons verder varimiddag bezigg houden.

\section{De Grondwet van 1848 en Kamerontbinding: het normatieve kader}

Door de grote Grondwetsherziening van 1848 werden twee vormen van kamerontbinding geintroduceerd'. Een wijziging van de Grondwet zou voortaan verplicht samengaan met ontbinding van beide kamers der Staten-Generaal, nadat het wijzigingsvoorstel in eerste lezing door de kamers zou zijn aanvaard. Zo zouden de kiezers zich, door hun woorkeur woor voor- of tegenstanders van deze wijziging, kunnen uitspreken over de herziening. Een verkiezing die dichtbij het referendum stond ${ }^{6}$. En staat, want nog immer gaat grondwetsherziening gepard aan kamerontbinding, al beperkt die zich sedert 1995 tot de Tweede Kamer.

Datrinaast kent de Crondwet sinds 1848 de regering de bewoegdheid toe tot ontbinding van ofwel de Tweede of de Eerste Kamer. Daaraan zijn geen woorwaarden verbonden, maar de regering zal daartoe besluiten indien zij redenen heeft te twijfelen aan de representatiwiteit van een 
dezer kamers onder haat respectieve kiezers. Die twijfel zou kunnen opkomen bij een conflict tussen regering en parlement over voorgenow men wetgeving of over het regeringsbeleid. In dit geval spreken wij daarom van "conflictontbinding". In zulke conflicten dienen kiezers op te treden als arbiter tussen regering en parlement.

In de praktijk van de eerste decennia na 1848 zow het recht van ontbinding hoofdzakelijk dienen om conflicten te beslechten tussen de koning en hem welgezinde mimisters enerzijds en hem weerstrevende kamermeerderheden anderzijds. Bij deze gevechten om de macht des konings zou het parlement uiteindelijk als de sterkste boven komen drijwen. Nog niet in 1853, want toen wisten Van Hall en Donker zich van een koningsgezinde - of zo men wil: antikatholieke - meerderheid te verzekeren, zij het niet voor lange $\mathrm{tij}^{\mathrm{s}}$.

In diezelfde eerste decennia na 1848 werd het recht van ontbinding gezien als een persoonlijk recht van de koning, a! moesten ministers voor een besluit daartoe verantwoordelijkheid aanvaarden. Ministers dienden het vertrouwen van de koning te genieten, niet per se dat van het parlement. Pas vele jaren later zou het parlementaire vertrouwen beslissend worden voor handhaving of verwijdering van ministers".

Toch is er in het geval van kamerontbinding een rol gebleven voor de koning, of beter nog: voor elk staatshoofd, hetzij koning hetzi] president, in een parlementaire democratie*. Om bij het koningschap te blijven, zowel in Groot-Brittannie als in België en Spanje kent de constitutie als. mede de bijbehorende doctrine aan de persoon van de koning een rol van betekenis toe als het gaat om een ontbindingsbesluit. Nu niet meer om de koning te laten beslissen wie hij als ministers om zich heen wil, maar ter voorkoming van al te gretige pogingen om een parlement natar believen te vervangen. Ontbindingsbesluiten zijn immers bijna steeds riskant, omdat zij pogen de politieke verhoudingen te forceren ten gunste van de regering en haar parlementaire vrienden en tegelijk omdat ze bijna altijd een breuk betekenen in het mandaat dat kiezers hebben gegeven voor een bepaalde termijn. Die valt niet naar believen in te korten, tenzij daar overtuigende argumenten voor bestaan. Niet toevallig bepaalt de Spaanse Grondwet" dat de koning er is om op de goede democratische zeden te letten en dus dat hij het is die de cortes Generales ontbindt. De Spaanse regering heeft zijn steun nodig voor ontbinding. Ook de Belgische doctrine kent aan de koning een "zeden 
bewakende rol" toe als het gaat om kamerontbinding, al heeft die onder de federalisering wel te lijden gehad'. Ongeveer hetzelfde geldt voor Denemarken; het Zweedse en het Noorse koninkrijk kennen geen ontbindingstecht.

A fortiori geldt deze "zeden bewakende rol" misschien wel in de Britse situatie. Kamerontbinding is daar de standaardprocedure om verkiezingen uit te schrijven. Er geldt slechts een maximumtermijn van vijf jaren alvorens de regering verplicht is tot ontbinding van het Lagerhuis over te gaan. Een regering, in feite de Prime Minister, heeft echter de wrijheid die periade nalar welgevallen te bekorten. Toch is er in de doctrine overeenstemming over dat zulk besluit niet dan met expliciete steun van de koning mogelijk is; juist daar waar ontbinding de normale praktijk is en niet de uitzondering, zoals in continentaal Europa. Die consensus is er onder "oude" staatsrechtgeleerden, zoals Dicey en Jennings, maar ook bij de jongere vakbroeders zoals Bogdanor". Misschien zult $U$ zeggen: ach, dat is de doctrine en die is waak meer op de hand van de koning dan de politieke praktijk. Maar wat dacht $U$ van Tony Benn, de radicaal-linkse Labourparlementariërin? Ook hij houdt strak vast aan's komings recht te beslissen over de dissolution of Parliament.

Om de hantering van het ontbindingsrecht niet volledig in opportunistische handen te doen vallen, moet het hoofd wan de staat een zekere rol behouden in besluiten daarover. Zijn handtekening moet waarbarg zijn dat een besluit tot ontbinding weloverwogen en ten dienste van het zuiver functioneren van regering èn parlement is genomen. Dat geldt in beginsel ook woor de Nederlandse situatie". Niet toevallig spreekt. P.J. Oud in zijn "Constitutioneel recht" over het "koninklijk ontbindingsrecht", ook al is de grondwetsbepaling erover in 1983 verplaatst van het hoofdstuk over "macht des konings" (nu: "de regering") naar het onderdeel over de Staten-Generaal en wordt nu eenvoudigweg gesproken van een koninklijk besluit'. Ontbinding kan echter nog immer niet buiten het hoofd van de staat om.

De vraag kan worden opgeworpen of in Nederland de beoordelingsruimte van cle koning niet erg klein is geworden, zelfs als hij reden zou hebben tot ernstige kritiek op de voordracht tot ontbinding. In oktober 2002 sprak immers niet alleen het kabinet zich daarvoor uit, maar met opvallende hartstocht ook zo ongeveer de hele Tweede Kamer. Dit, terwill het zeer de vraag was of, ter oplossing van het conflict van en met 
twee ministers wan de LPF, nieuwe kamerverklezingen nodig wären. Er was immers geen sprake wan een conflict tussen kabinet en Tweede Kamer, noch van een onheelbaar gebleken breuk in de coalitie. vervolgens had iedere partij haar eigen redenen om de verkiezingen van 15 mei 2002 nog eens dunnetjes over te doen. Voor de koningin was er geen enkele beoordelingsmarge - op zichzelf nuttig en noodzakelijk meer over". De voordracht bereikte haar bovendien een dag nadat haar echtgenoot in de Nieuwe Kerk van Delft was bijgezet; onkieser kon het niet. Haar enige troost, als het er een was, kon zijn dat het niet de eerste keer was in onze parlementaire historie dat de vorst in een kwestie van kamerontbinding rauwelings met de rug tegen de muur werd gezet. Eerder was dat al eens gebeurd in 1894 ; ik kom daar straks op terug.

Uiteraard gaat het vandaag, ook in ons land, niet meer om het persoonlijk "welgevallen" van de koning. Dat is echter iets anders dan te geloven dat er dus voor hem helemaal geen rol meer bestaat. Zijn positie bestaat er nu in als hoofd van de staat te waken over het zuiver constitutioneel handelen van de staatsinstellingen. Dat moge nergens expliciet in de Nederlandse Grondwet zijn wermeld, zoals dat in de Spaanse Grondwet van 1978 wel het geval is. Uit de positie van staatshoofd vloeit echter voort dat het Nederlandse koningschap daartoe constitutioneel is bestemd. Het dient daarvoor dan ook voldoende ruimte te behouden, a fortiori in een tijd waarin politici in regering en parlement het met de staatsrechtelijke zorgvuldigheid niet zo nauw nements.

\section{Grondwetsontbinding in de praktijk: "verdonkeremanen" van kie- zersvoorkeur}

De geschiedenis van de Nederlandse ontbindingspraktijk is op zijn minst opmerkelijk. Dat geldt voor beide vormen van ontbinding. Wij

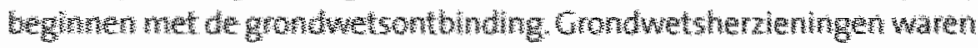

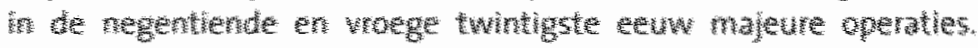

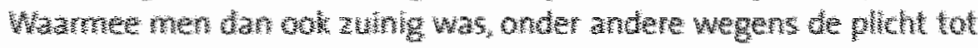

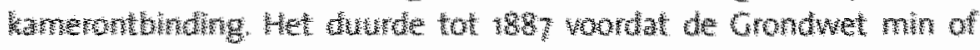

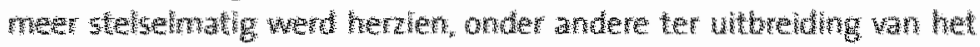

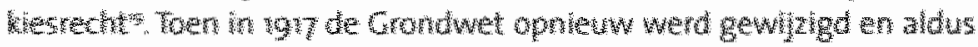

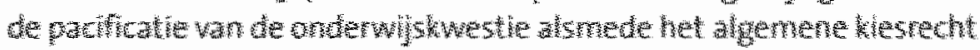
mogelly ward gewak, probed den de grote pariformates met suc-

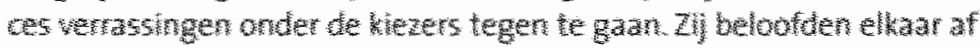

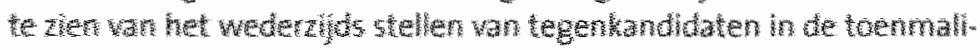


ge klesdistricten ${ }^{2 .}$. Zo konden beide kamers in vrijwell ongewijzigde samenstelling terugkeren en met de vereiste gekwalificeerde meerderheid de grondwetsherziening aanvaarden. Het was blijkbaar niet de bedoeling dat de kiezers de kans kregen actief te interveniëren.

Nog eenmaal mochten de kezers echt beslissen, in 1948, toen het ging om de grondwetsherziening die de betrekkingen met het opstandige Iridonesié op nleuwe wijze vorm gaf. Grondwetsherziening moest vooraf gaan aan daadwerkelijke dekolonisatie, vond de grondwetgever. Dat het allemaal anders uitpakte dan door de kiezers was bepaald (en formeel beperkt!) dat laten wij nu maar terzijde. Het was ook een tikkeltje naief om te geloven dat een Nederlandse kiezersuitspraak over de vaorkeuren van de Indonesische bevolking zou kunnem beslissen ${ }^{21}$.

Al vanaf 1922 werd de besluitvorming van de kiezer aver grondwetswijziging stelselmatig samengebracht met de reguliere verkiezingen van de Tweede Kamer: ${ }^{2 a}$. Formeel leidde dat tot ontbinding wan beide Kamers, maar er was geen kiezer die het nog merkte. Aan te nemen valt immers dat niemand uwer zich heeft gerealiseerd dat zij of hij, bij woorbeeld, in 1956, of in 1963, of in 1971, heeft beslist over min of meer gewichtige wijzigingen van de Grondwet".3. Dat geldt dus ook voor 1982 , toen de Nederlandse bevolking heeft beslist over de algehele herziening van de Grondwet die een jaar later van kracht is geworden. Zodoende is het referendumelement in de grondwetsontbinding intussen effectief verdonkeremaand.

Dit "verdonkeremanen" van grondwetswijzigingen heeft twee curieuze effecten gehad. De Nederlandse bevolking, ik zei het al, heeft zich een aantal malen formeel maar onwetend over belangrijke wijzigingen in ons constitutionele bestel uitgesproken. In 1952 heeft zij, bij voorbeeld, ingestemd met de bepaling in de Grondwet die toestaat dat Nederlands soevereiniteit wordt doorbroken door de Europese supranationale instellingen, maar aok door de bepalingen van de Europese conventie voor de Rechten van de Mens's. Zou die instemming er ook zijn geweest, als de Nederlanders zich daar expliciet over hadden moeten uitspreken?

Het kan echter nog gekker. In 1998 heeft de bevolking zich formeel uitgesproken vóór de invoering van het correctieve wetgevingsreferendum. Dat moeten wij althans afleiden uit de positieve beslissing van de 
Tweede Kamer in tweede lezing, in datzelfde jaar. Vervolgens hield in de Eerste Kamer het lid Wiegel de invoering ervan in 1999 persoonlijk tegen, alsofer geen kamerontbinding was geweest. Een nieuwe kiezersuitspraak kwam er, formeel althans, in $200 z_{3}$ maar daarna werd bij de kabinetsformatie besloten dat de kiezers nu tegen het referendum hadden gestemd. Opmerkelijk, want Pim Fortuyn was bij leven een uitgesproken voorstander daarvan geweest. Zijn politieke nazaten lieten Pims doorgaans zo vereerde "gedachtegoed" tijdens de formatie eventjes voor wat het was. Alleen het CDA had van zijn afkeer van het referendum nooit een geheim gemaakt. Alweer, wat zou er zijn gebeurd als de kiezer zich, zoals de bedoeling is van grondwetsontbinding, expliciet had kunnen uitspreken?

Natuurlijk is $U$ dat allemaal ontgaan; juist dat geeft beide kamers de gelegenheid de kiezers te raadplegen over niet onbelangrijke staatshervormingen en zich daar vervolgens niets van aan te trekken. Er zijn mensen - niet de minsten - die onder andere op deze ogenblikken de vraag opwerpen of Nederland wel een democratie is of eerder een "regentenrepubliek met grondrechten ${ }^{\text {is }}$.

Er is nog een tweede, curieus effect. Werken aan de Grondwet is verworden tot het veilige en ongeziene ambacht van een groepje ambtenaren van het Ministerie van Binnenlandse Zaken, al dan niet in samenwerking met externe commissies van deskundigen ${ }^{25}$. Tweede-Kamerleden laten dit Hogere Knutselwerk aan de experts over, met uitzondering van de parlementariërs die door hun achtergrond zijn geïnteresseerd en degenen die als woordvoerder moeten optreden. Natuurlijk valt er altijd wel wat te veranderen - belangrijk en onbelangrijk - zodat sinds de algehele grondwetsherziening van 1983 bijna elke verkiezing er een is geweest met grondwetsontbinding ${ }^{7}$. Inderdaad, dikwils met onderwerpen waar geen kiezer voor van huis zou zijn gegaan, als hij zich er expliciet over had moeten uitspreken. intussen zijn wij daar allemaal zozeer aan gewend geraakt dat bijna niemand er meer de absurditeit van ziet. 
Van lieverlee is de regering steeds slordiger geworden met de indiening van herzieningsvoorstellen in tweede lezing ${ }^{28}$. Die behoren wanouds aanstonds na het aantreden van de nieuwe Tweede Kamer bij haar te worden ingediend. In 2002 liet het demissionaire kabinet-Kok indiening geheel achterwege en kwam zijn opvolger met de herzieningsvoorstellen in stukjes en beetjes op 10 september, 24 september en zelfs 13 december, toen het kabinet-Balkenende zelf alweer demissionair was. Dat deed zelfs discussie ontstaan over de vraag of behandeling in tweede lezing wel is toegestaan, indien intussen de Tweede Kamer opnieuw is ontbonden. Terecht heeft de Raad van State geoordeeld dat zulk een "tweede ontbinding" voor behandeling in tweede lezing van grondwetswijzigingen als irrelevant moet worden beschouwd.

De wijze waarop wij in Nederland met onze Grondwet omspringen getuigt al bij al van weinig respect voor de waarden en normen van ons politieke stelsel. Die houding wordt des te navranter, als wij van nieuwe burgers in ons land verlangen zich te richten naar onze Grondwet ${ }^{29}$. Daar valt op zichzelf veel voor te zeggen, maar dan zouden wij met de herzieningsprocedure een stuk zorgvuldiger te werk moeten gaan en wooral veel opener dan wij doen. De herzieningsprocedure staat hoe dan ook symbool voor het respect van regering en parlement voor de Grondwet. Het is trouwens ironisch om vast te stellen dat de negentiende-eeuwse grondwetgever zichzelf en zijn kiezers heel wat serieuzer nam dan zijn eenentwintigste-eeuwse rechtsopvolger.

\section{Conflictontbinding in de praktijk: neutraliseren van kiezersvoorkeur}

De tweede vorm van kamerontbinding, de conflictontbinding, heeft in Nederland een al even merkwaardige historie beleefd. Aanvankelijk, zoals in 1853 maar ook nog enige keren nadien, was het een effectief instrument om conflicten tussen regering (meestal de koning) en Tweede of Eerste Kamer te beslechten. Nog in 1886 stuurde Heemskerk de Tweede Kamer nar huis om de daar ontstane impasse over de grondwetsherziening te doorbreken, met succes ${ }^{30}$.

Maar, acht jaar later ging het grondig mis. Toen de liberale minister Tak van Poortwliet zijn zin niet helemaal kreeg met zijn radicale kiesrechtvoorstellen, vroeg hij de regentes, koningin Emma, de Kamer te ontbinden. Het verzoek kwam voort uit een geheime afspraak die hil al in 1891 met de kabinetsformateur, Van Tienhoven, had gemaakt, maar waar de regentes buiten was gehouden. Emma was daarover terecht not 
amused; tussen haar, Van Tienhoven en Tak is het nooit meer goed gekomen ${ }^{33}$.

De ontbinding had treurige consequenties. Niet alleen verloor Tak het gevecht om het kiesrecht. Dat zou men nog kunnen beschouwen als het risico van het vak. Ernstiger was dat over zijn kiesrechtwoorstellen vijiwel alle politieke stromingen blijvend innerlijk verscheurd raakten: hiet liberalisme brak in drieën; de Anti-Revolutionaire Partij brak in tweeën en de nog ongeorganiseerde katholieke groepering raakte eveneens in innerlijk conflict ${ }^{32}$. Voor de verhoudingen tussen de naar anarchisme neigende Domela Nieuwenhuis en de jonge SDAP, in 1894 opgericht, kan deze conflictontbinding evenmin bevorderlijk zijn geweest ${ }^{33}$.

Kamerontbinding bleek weinig geschikt om een conflict tussen regering en parlement tot een goed einde te brengen, indien politieke partijen innerlijk zijn verdeeld. Geen wonder dat ze daar sedertdien ook niet meer voor is gebruikt ${ }^{34}$.

Tot 1940 komen wij het fenomeen in zijn klassieke vorm mog maar twee keer tegen: eerst als Abraham Kuyper de Eerste Kamer in 1904 laat ontbinden wegens haar liberale verzet tegen zijn HogerOnderwijswet. Hij kan zich die ontbinding veroorloven, omdat hij weet dat de Provinciale Staten in het land - het kiescollege van de Eerste Kamer - intussen in meerderheid op zijn hand zijn geraakt"s. In 1933 laat Ruys de Beerenbrouck de Tweede Kamer ontbinden in verband met een op zichzelf weinig belangrijk conflict over de opheffing van een aantal rechtbanken, een bezuinigingsvoorstel van de minister van Justitie, J. Donner. Het eigenlijke oogmerk van Ruys is echter de vervroeging van de normale Kamerverkiezingen met enige maanden. Ruys is zich er immers van bewust dat zijn kabinet, gegeven de ernstige gevolgen van de Grote Depressie, is uitgeregeerd ${ }^{36}$.

In de "pacificatiedemocratie" die Nederland is geworden en die, dankzij algemeen kiesrecht en evenredige vertegenwoordiging. vaste voet heeft verkregen, past de klassieke toepassing van het recht van ontbinding feitelijk niet meer. Van de ervaringen in 1894 is geleerd dat daar slechts ongelukken van kunnen komen. In het algemeen is deze pacificatiedemocratie, uitgaande van lijdelijkheid onder de bevolking, niet gebouwd op rechtstreekse interventie van de kiezers, noch in het geval van politieke conflicten noch bij nood. 
zakelijk geachte wijzigingen van de Grondwet? ${ }^{3 x}$. En maal oordelen per vier jaar: daar moest het maar bij blijuen.

Toch zal blijken, na 1945, dat het daarbij niet altijd kan blijven. Kamerontbinding blijkt toch een geschikt instrument te zijn om politieke impasses te doorbreken: niet langer echter in geval van een conflict tussen regering en parlement, maar bij een conflict tussen samenwerkende partijen in regering en parlement beide. Kamerontbinding wordt, naar het woord van J.J. Vis, tot "zelfontbinding"

In Nederland* is die formule voor het eerst toegepast in 1958 toen de rooms-rode coalitie ten onder ging aan politieke slijtage. Het vierde kabinet-Drees was gevallen op onenigheid over belastingvoorstellen tussen minister H.J. Hofstra (PvdA) en een kamermeerderheid, aangevoerd door de fractie van de Katholieke Volkspartij, een van de grote regeringsfracties. De daaruit voortkomende breuk tussen de Partij van de Arbeid en de KVP bleek niet meer te lijmen. De als altijd verdeelde KVP-fractie wist daar aanvankelijk niet goed raad mee, totdat L.J.M. Beel als formateur een oplossing bedacht van een duivelse schoonheid. Hij vormde een zogenaamd "interim-kabinet" van KVP, ARP en CHU (nog altijd met een kamermeerderheid) dat als opdracht kreeg ontbinding van de Tweede Kamer te bevorderen en intussen de belangrijkste nog af te handelen voornemens als volwaardig kabinet aan te pakken, waaronder de gewraakte belastingvoorstellen, alsmede de Algemene Weduwen-en Wezenwet. Het duivelse van zijn oplossing zat daarin dat zodoende de PudA de kans werd ontnomen tot de volgende verkiezingen twee jaar lang oppositie te voeren en haar alanhang intussen te vergroten. Intussen kon er wel "echt" worden geregeerd. In het voorjaar van 1959 vonden de verkiezingen plaats, leidend tot een nederlaag voor de PvdA, waarna de KVP de handen vrij had en een coalitie vormde van christelijke partijen en de WVD onder leiding van de Brabantse commissaris wan de koningin, dr. J.E. de Quay.

Beels ingeving zou school maken, want zij werd herhaald na de "Nacht van Schmelzer" in 1966, toen KVP en PvdA opnieuw met elkaar in conflict waren geraakt. Het was opnieuw Beel die een interim-kabinet vormde met dezelfide opdracht als in 1958. Overigens zou dezelfde constructie van interim-kabinet en kamerontbinding in 1982 nog eens met succes worden toegepast, toen het kabinet Van Agt II uit elkaar viel, zij het niet door een conflict in de Tweede Kamer maar in het kabinet zelfto. 
Wat dit gebruik van Kamerontbinding pas echt duivelse trekken bezorgde was, dat de kiezer in het ongewisse werd gelaten - net als bij gewone werkiezingen, trouwens - over wat er met zijn stem zou gaan gebeuren. Ondanks het feit dat het om een conflictontbinding ging en ondanks het feit dat dit conflict aan de kiezer werd voorgelegd, hielden de christelijke partijen maar ook de PvdA en de WD de handen wrij om na de verkiezingen naar bevind van zaken te handelen. Toegegeven zij, dat het telkens kwam tot partnerwisseling: de PvdA werd na de verkiezingen van 1959, 1967 en 1982 vervangen door de WVD. In 1989 werd daarentegen, zonder constructie van een interim-kabinet, de WD vervangen door de PydA.

Bijzonder is overigens de aanpak geweest van de crisis in het kabinetBiesheuvel in 1972. Dat zette al na een jaar DS'70 als regeringspartner op straat, maar regeerde als minderheidskabinet kortstondig door, met de opdracht tot kamerontbinding, tot de verkiezingen op 29 november van dat jaar. Dit alles, in de stiekeme hoop dat dit kabinet een meerderheid zou krijgen, ook zonder DS'70. Die kwam er niet'. Hoewel Biesheuvel zelf wel anders had gewild, moesten ook toen de kiezers maar raden wat hun keuze voor gevolg zou hebben. De aanpak van de crisis in 2002 herinnert sterk aan die van 1972 , met de LPF in de tragische rol van DS'70.

Bijzonder was evenzeer de aanpak van het conflict over de grondpolitiek waarmee het kabinet-Den Uyl, nog geen drie maanden voor de verkiezingsdag, in maart 1977 uiteen vielaz. Er werd wel besloten tot kamerontbinding, maar daartoe werd formeel verzocht door het demissionaire kabinet, met inbegrip van de dissidente ministers van de KVP. Zo bleef een tweede kabinet-Den Uyl tot de mogelijkheden behoren. Na de voor de toenmalige minister-president zo succesvol verlopen werkiezingen leek het daa r ook langdurig op uit te draaien. Totdat er, eind 1977, toch een kabinet kwam zónder de PvdA en mét de VvD erin; de verkiezingen hadden daartoe de ruimte geschapen, al hadden weinigen dat aanstonds door. Jaap Burger, de oude vos uit de PvdA, had het al ooit gezegd: Nederlandse verkiezingen lijden aan "structurele uitślagloosheid".

De vraag is natuurlijk hoe dat komt? Is dat niet omdat partijen zelden woorafgaand aan werkiezingen duidelijk wensen te maken naar welke samenwerking hun woorkeur uitgat en de kiezer principieel in het ongewisse laten? De belangrijkste uitzondering was de reguliere verkie- 
zing van 1986 toen CDA en VVD een expliciete voorkeur uitspraken voor woortzetting van hun samenwerking. Die voortzetting kwam er dan ook, omdat de coalitie haar meerderheid ruimschoots behield en juist het CDA, dat van haar erflaters een traditie had overgenomen van niet-kiezen vooraf, groot electoraal succes behaalde. Drie jaar later was het met dit kiezen vooraf, ondanks een conflict met de WVD en ondanks Kamerontbinding, weer over. Daarnaast is er het voorbeeld uit 1998 van de "parse" coalitie die er geen geheim van maakte de samenwerking te willen continueren.

Intussen had zich een uiterst paradoxale ontwikkeling voorgedaan ${ }^{43}$. Nadat in éến mandaatperiode, tussen 1963 en 1967, drie kabinetten van verschillende samenstelling waren gewormd, concludeerde vooral de PvdA dat wisseling van regeringspartners alleen nog kon plaatswinden na kamerontbinding en verkiezingen. Over zo'n wisseling moest de kiezer kunnen oordelen. Daar viel, bij wijze van politieke fatsoensnorm, iets woor te zeggen en inmiddels denken alle partijen in de Tweede Kamer er zo over. De ijzeren consequentie van die fatsoensnorm echter, duidelijkheid verschaffen over de samenstelling van de toekomstige coalitie, is nooit getrokken. De kiezer wordt na de breuk wel geacht te arbitreren, maar zonder te worden ingelicht tussen wie of wat. Aldus is niet alleen het effect van kamerontbinding in het algemeen geneutraliseerd maar ook de intussen algemeen aanvaarde fatsoensnorm. Dat, terwijl alle partijen bij de verkiezingen de relatie leggen tussen parlementaire samenstelling en toekomstig regeringsbeleid; ja, hun lijsttrekkers presenteren als kandidaat voor het ambt van minister-president. Alweer, het is dat wije eraan gewend zijn maar het is niettemin een constellatie met licht absurde trekken. Over langdurig sllepende kabinetsformaties hebben wij het dan niet eens gehad ${ }^{44}$.

Wat te doen? Ofwel, wij zouden deze niet werkende fatsoensnorm terzijde moeten leggen en moeten ophouden kabinetscrises standaard te laten uitlopen op nieuwe verkiezingen en dus kamerontbinding. Op de grondslag van reguliere verkiezingen is doorgaans een keur van coalities te vormen ${ }^{45}$. Als dan de ene coalitie breekt, wordt zij vervangen door een andere zonder de kiezer voortijdig lastig te vallen met een arbitrage die geen arbitrage is. Ofwel, wij gaan alsnog het voorbeeld van Van Hall en Donker Curtius volgen. Dat betekent dat na een breuk tussen partijen eerst een nieuwe coalitie wordt gevormd met een nieuw programma en met nieuwe ministers. Die coalitie gaat vervolgens over tot 
kamerontbinding en werf actief de steun van de kiezers. Die weten dan waarover zij moeten beslissen. Het spreekt vanzelf dat zo'n coalitie op de diag van de verkiezingen haar ontslag niet bij de koning indient, tenzij uit de verkiezingen is gebleken dat zij van de kiezers geen meerderheid heeft verkregen.

U zult wellicht denken: ach, dat kon misschien 150 jaar geleden, maar het zijn nu toch andere tijden. In dat geval verwijs ik U graag naar het woorbeeld van Helmut Kohl in de Duitse Bondsrepubliek ${ }^{46}$. In het najaar van 1982 werd hij gekozen tot Bundeskanzler met behulp van een constructieve motie van wantrouwen tegen de zittende kanselier Schmidt. Hij stelde zijn regering van CDU/CSU en FDP samen, compleet met programma en ministers en met een meerderheid in de Bondsdag. Niettemin - de Nederlandse fatsoensnorm leek wel naar de Bondsrepubliek overgewaaid - wond Kohl dat hij zulk een partnerwisseling niet moest doorzetten buiten de kiezers om en, wie weet, wilde hij en passant de SPD een forse nederlaag bezorgen. Hoe dan ook, met enig forceren van het West-Duitse Grundgesetz dat daar eigenlijk niet in voorzag, wist hij een ontbinding van de Bondsdag te bewerkstelligen. De WestDuitse bevolking bezorgde zijn partij en de liberalen een comfortabele meerderheid. Bijkomend voordeel: in economisch moeilijke tijden kon hij vier jaar lang zijn werk doen. Hoe dan ook, de kiezer kreeg de kans te beslissen. Kan iemand uitleggen waarom zoiets in Nederland niet zou kunnen?

\section{Kamerontbinding, verkiezingen en de machtsvraag: voorbij de paci- ficatiedemocratie}

Nederland is nog immer een land van politieke minderheden, maar het is geen "pacificatiedemocratie" meer waarin het primair gaat om de bescherming van levensbeschouwelijke politieke en maatschappelijke organisatie. In de pacificatiedemocratie paste tot op zekere hoogte het op velige afstand houden van de kiezer en het voorzichtig opereren met. de vorming en wisseling van coalities.

"Sociologisch kiezen", op basis van levensbeschouwing en sociale klasse, heeft plaats gemaakt voor meer wisselend kiezen op politieke stand punten en politieke leider $5^{4}$. Partijen zelf kiezen in hun campagnes woor een propaganda die een directe relatie legt tussen hum relatieve kracht en de invloed daarvan op het regeringsbeleid. De "machtsvraag", zoals dat tegenwoordig wordt genoemd, speelt daarbij meer dan eens, 
zij het weinig consequent, de hoofdrol. Ik heb al gewezen op het belang daarvan in 1986 en 1998 waarbij woortzetting wain de bestaande coalitie centraal stond. Meer en meer staam werkiezingscampagnes in het teken van het toekomstige minister-presidentschap. Nederland verliest, Europees vergeleken, aan unieke karaktertrekken, ook al is er nog een zekere voorkeur voor brede coalities.

Er is nog een ander verschijnsel dat wijst op het einde van de pacificatiedemocratie. Kiezers zijn nu al twee keer in stat en bereid gebleken om een zittende coalitie, ook al heeft zij brede parlementaire steun, bij kamerverkiezingen eenwoudig weg te vagen. Dat gebeurde in 1994, toen CDA en PvdA tezamen 32 zetels verloren, en opnieuw in 2002, toen PudA, WD en D66 tezamen zelfs 43 zetels kwijt raakten. Deze machtsuitoefening door de kiezers kan worden uitgelegd als een teken van volatiliteit en ongedurigheid ${ }^{36}$, mar zij kan er ook op wijzen dat de kiezers weten wat zij doen: een coalitie doelbewust wegstemmen. Partijtrouw telt daarbij blijkbaar belangrijk minder zwaar dan politiek richting kiezen. Deze electorale machtsuitoefening zou door politieke partijen ook in meer constructieve vorm kunnen worden omgebogen: de kiezer hoeft dan niet meer alleen ergens tegen te zijn. hij kan ook ergens voór zijn. Dat vergt, zeker in het geval van kamerontbinding, maar waarschijnlijk bij verkiezingen in het algemeen, dat partijen vóór de verkiezingen coalities sluiten en daarvoor steun zoeken bij de kiezer en niet pas na afloop ${ }^{\text {tis. }}$

Bij wijze van illustratie van deze stelling een klein gedachte-experiment. Stel eens dat de heren Melkert en Dijkstal ons in 2002 niet als een koppel klassieke regenten in het ongewisse hadden gelaten over wat zij met onze steun dachten te doen, maar ons vanaf het najaar wan 2001 hadden geconfronteerd met de keuze voor, bij voorbeeld, een coalitie van PvdA CDA en Groen Links - toen een reële optie - ofwel een caalitie van VVD en CDA, al dan niet in samenwerking met D66, een minstens zo reële optie? Natuurlijk had dat een Iuxepositie voor het CDA betekend, maar wat belangrijker was: WVD en PvdA waren niet meer tot wruchtbare samenwerking in stat. Stel dat zulke keuzes vanaf september 2001, na het aangekondigde vertrek van minister-president Kok, waren voorgelegd en "uitgevent" bij de kiezer. Zou Pim Fortuyn dan ook zon succes hebben gehad? zou het niet waarschijnlijker zijn geweest dat hij nu nog columnist en spreker op "bruiloften en partijen" van bedrijven en instellingen zou zijn en, belangrijker, nog onder de levenden? Zou het CDA dlan 
de sterke parlementaire machtspositie hebben herkregen waarover het sinds 2002 weer beschikt?

Dit is allemaal iffy history; niet echt passend in een wetenschappelijk betoog. Wat ik ermee heb beoogd is te laten zien dat de macht van de kiezer minder schrikaanjagend kan zijn voor regering, parlement en politieke partijen, mits aan de "Natie de aanspraak" wordt toegekend "te weten wat zij van een nieuw bestuur mag wachten". Daar hebben wij geen ander kiesstelsel voor nodig; het goede voorbeeld van twee, toch niet erg radicalle liberalen uit de negentiende eeuw of, als $U$ dat liever hebt, dat van de Duitse christen-democraat, Kohl uit 1982 volstaat. 
Mifheer de Rector Magnificus, Dames en Heren.

Aan het einde gekomen van deze rede will ik graag mijn dank uitbrengen aan allen die actief hebben bijgedragen aan mijn benoeming tot hoogleraar in mijn geboortestad: het College van Bestuur, de decaan er het bestuur van de Faculteit der Rechtsgeleerdheid en meer in het bijzonder de initiatiefnemers in de Capaciteitsgroep Publiekrecht, Ad Geers. Aalt-Willem Heringa, Frits stroink en Luc Verhey, die mij met Mastrichtse gasturifheid hebben verleids en die nu mijn hulpvaardige collega's zijn, tezanen overigens met Gert-lan Veerman die net als ik recent in Maastricht is alangetreden. Dank ook aan mijn voorganger, Erik Jurgens, die het belang van deze leerstoel in Maastricht heeft aange. toond.

Myn dankbaarheid gaat ook uit naar de vriendelijke ontwangst door een competente en toegewijde staf met een unieke en leerzame, niet louter Nederlandse samenstelling. Deze intreerede en de eerste, buttengewoon aardige kontakten met de studenten aan de UM zijn er om aan hen te tonen wat ik met mijn leeropdracht beoog: juridische normen en opvattingen te platsen in een tegelijk historische en politiekwetenschappelijke context. Wiet orn aan het staatsrecht afbreuk te doen maar eerder om zijn kritische functie te versterken.

Hier voor U staande bekruipen mij een paar eigenaardige associaties. kijk ik goed om mij heen, dam zie ik in deze aula de kapel van het voormalige Huis van Bewaring, waar ik ooit als koorknaap met Kerstmis de gedetineerde mannen en vrouwen samen met andere jongens letwat mocht opvrolijken. Dat was tevens mijn eerste - en om U gerust te stellen: ook mijn enige - kennismaking met het inwendige van een gevangenis.

Eir is een tweede associatie die nog heel wat meer ingrijpt: in dit gebouw, toen dus Huis wan Bewaring, heeft mijn vader eind 1941 een kheine veettien dagen doorgebracht op beschuldiging te behoren tot een Mastrichtse verzetsgroep. Nu hoorde hij daar niet bij, maar hij makte zich wel a an andere tegen de Duitse bezetter gerichte activiteiten "schuldig" en bovendien wist hij van werk en samenstelling van de met hem gearresteerde groep mensen. Het werd dus een kwestie van zwiggen en zich vall de domme houden. De SD trad in die beginjaren, geleld door een Akense politieofficier, nog relatief correct op. Mijn vader 
werd dan ook wegens gebrek aan voldoende bewijs op vrije woeten gesteld. Er bestaat nog een fotootje van hem, gemaakt kort na zijn vrijlating: het toont een sterk getekend gezicht. $U$ begrijpt, dat gezicht zie ik voór mij als ik hier sta.

Mijn ouders zijn er niet meer; zij hadden beiden 109 jaar oud moeten worden om deze dag te kunnen meebeleven. Dat is te veel gevraagd. Wel betreur ik zeer de afwezigheid van mijn oudste zuster die vorig jaar is overleden. Des te blijer ben ik met de komst van mijn andere zuster en broers. In het bijzonder geldt dat woor mijn zus die in de jaren van bezetting mijn moeder-plaatsvervangster is geweest en die vandaag 78 jaar is geworden. Aam haar draag ik deze rede op.

ik heb gezegd.

N.B.: Een eerdere versie van deze tekst is ter commentaar voorgelegd alan H. Daudt en A.JM. Groenewegen. Voor hun suggesties ter verbetering en verduidelijking ben ik beiden dankbaar, ook als ik sommige ervan niet heb Dvergenomen. 


\section{Literatuur}

1 Eer mool maar ook tameljk partijdig (pro-Thorbecke) overzicht wan de gebeurtenissen rond het herstel van de bisschoppelijke hierarchie in Nedertand geeft nog altyd. Wu, wan Welderen baron Rengers, 5 chets eener par. iementaire geschiedenis wan Nederland, wan 1849 tot 189 . Eerste Deel, "s Gravenhage 1905 (tweede, herziene en bijgewerkte uitgave), 84-104. Een wer korte versile daarvan met dezelfoe bias levert: PI. Oud, Honderd Jaren, hoofdzaken der Mederlandse sta atkundige geschiedenis, 1840 - 1940, Assen 1946, 4047. Het boek is inmiddels, bewerkt door I. Bosmans, werschenen als deel I van staatkundige vormgeving van Nederland, Assen 1997 (elfde druk). Nieuwe

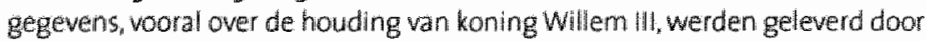
E. van Raalte, Staotshoofd en ministers, Nederlands constitutionele monarchie histrorisch staatsvechtelik belkcht: Zwolle 1977,94-101. Zie ook: Ronald van Raak, In nawm van het walmaakte, conserwatisme in Nederland in de negentiende eeww, wan Gerrit-Jan Muder tot Jan Heemskerk Azn. Amsterdam 2001, 69-100, en Jutjen Vis en Wim Janse (red.), Stof en storm, het herstel wan de bisschoppelike hierarchie in Nederland in 1853, actie en reactie, Hilversum 2002.

2 J.J. Vis zutet de voordracht tot kamerontbinding dan ook als een poging het Engelse voorbeeld te volgen, warbij een besluil tot ontbinding wordt ingegewen door het motief "populariteit bij de kezers" om te zetcen "in parlementaine steun op een geschikt moment". Mijns inziens gaat ale omschrijwing enigszins voorbij aan de in 1853 nog erkende persoonlike beslissingsifuimte van de koning. Dat Whlem lll in conflict was gekomen, door zilin Amsterdamse optreden, niet alleen met zijn ministers mar ook met een meerderheid van de Tweede Kamer, stond well wast. Zle. J. Vis De ontbinding van het parlement, monografie 4. Nederlands porlementsrecht, Groningen 1987,35 .

3 C.W. de Vries, De ongekende Thorbecke, Amsterdam 1950,66 -74.

4 Voor de tekst van de voordracht tot kamerontbinding zoals verschenen in de Statscourant in april 1853 : Vis, Ontbinding, $183-185$.

5 Het meest recente en meest grondige boek over kamerontbinding is dat van Vis, Ontbinding, uit 1987. Eerdere studles: H. wan Hoogendorp, De ontbinding der wolksvertegenwoordiging in de constitutionele monarchie, uit 1868 en E.J. Philips, Het recht van ontbinding, uit 1895 . Meer recent is de dissertatie wan $W$. de Kwalstentet, Het recht wan Kamerontbinding. Amsterdam 1968. Voor vergeligkend inzicht in partementsontbinding in de Europese Unie lalleen Zweden kent geen ontbindingsrecht; buiten de unie geldt dat in Europa woorts woor Noorwegen). L.P. Prakke en C.A.M. Kortmann, Het statsrecht wan de landen van de Europese Unie, Deventer 1998 , (wifde druk). Voor de wijzigingen in de teksten over het ortbindingsecht in de Nederlandse Grondwet zie: Van Hasselt, Verzameling van Nederlandse staatsregelingen en grondwetten. Aphen aan den Rijn 1987, (nadien zijn geen actualiseringen meer verschenen) en de min of meer "officiele" publicatie: De Grandwet 1987 . met: verwijzing per artikel naar overenkomstige bepolingen wan eerdere grondwetten, zwolle 1994, (twaalfde uitgave), de zog. "Roode Jurk". Ook daarvan is geen 
actueler wersie woorhanden. Woor de huidge tekst van de Crondwet, met inbegrip wan het gewijzigde artikel over grondwetsheriening (de Eerste Kamer wordt na eerste lezing niet meer ontbonden): C.A.M.M. Kortmann a... Grandwet woor het Koninkrijk der Nedertanden, tekst en commentaar, Deventer 1998. (art.137 Grw. op 138 en 139).

Ontbinding krachtens grondwetsherziening werd in 1848 geregeld in art. 197 (nu: art. 137); de conflictontbinding, formeel een ongeclausuleerd recht van de regering, werd in 18,48 wermeld in art. 70 thu: art 64 . Nog in een ander geval is sprake van (verplichte) Kamerontbinding indien een troonopwolger ontbreekt bij overlijden van de koning of indien op zulk fieit voon witzicht bestaat (nu: art. 30), waarwoor enigszins vergelijkbare bepalingen reeds bestonden wanaf 1814 .

6 Deze beslissende rol wan de kiezer makkte de Leidse hooglera thorbecke dan ook tot tegenstander wan het ontbindingsrecht. Enerzijos zag hij het als een onvoldoende ernstig nemen van de kiezers bij normale werkiezingen: zij gaven mandaat voor vier jaren en nilet woor zo lang als het de regering anstond. Voorts vond hij dat kiezers niet behoorden te worden betrokken in concrete conflicten tussen regering en parlement. Dat zag hij als een ondergraven wan het onathankelijk aordeel wan de volkswertegenwoordiger. Zile: IIR. Thorbecke, Aanteekening op de Grondwet, dee/ 7 , Lelden 184 (tweede witgave) $272-277$

7 Zie over de strijd om het primaat vam vertrouwen tussen koning en parlement en de daarvoor relevarite onitbindingen van de Tweede Kamer In 1853. 1866 en 1868: Wan Raalte, Staatshoofd, $94-123$.

8 Bij de regullere werkiezingen wan 1854 warbij, zoals destijds woorgescheven, de helft wan de kamerzetels werd vernieuwd, mam het a antal Thorbeckegezinde leden weer toe en verloor het koppel Wan Hall - Donker ten dele zijn comfortabele meerderheid van het jaar daarvoor. Zie: Van Welderen, Schets 1 . 105-143. Pikant is dat in 1853 de kiezers in het uitgesproken liberaal gezinde district Mastricht Thorbecke naar het Binnenhof afvardigden, hoewel Limburgse kiezers in het algemeen geneigd waren mannen te kiezen die op zijn minst in het district woonden maar er liefst ook waren geboren. Zie: Eric Lemmens, Aan Worst en Vaderland gehecht, doch tewreden zijn zif niet, Limburgse politici in Den Haog, 1839 - 7978 , Amsterdam 2004. 78-97.

9 Over de opvattingen van tidgenoten over het "primaat" wan vertrouwen. warbil parlementair vertrouwen in ministers als irelewat werd beschouwd: H.G. Lagemans, De leer der minusterlele verantwoordellkheid en hare toepassing in het Nederamdsche stoatspegt, Leiden 1855.33 . De Amsterdamse hoogleraar strujcken, gat in 1913 een goed beeld vari de gellel. delijkheid warmee het belang van parlementair vertrouwen is gegroeid waarbij, zijns inziens, zowel het stijgend gewicht van politieke partilen als de uitbreding van het kiesnecht van doorslaggevend belang zijn geweest. Zie: A.A.H. Struijcken, Grondwetsherzering, theorie en praktjk beschouwingen over staatsrecht en staatkunde, Amsterdam 1913. 127- 128. In nawalging van Struijkken heeft ook Donner ( $e$ in atere drukken Prakke met hem) het: belang wan de Kamerontbindingen van 9866 en 1868 gerelativeerd: Van der 
Pot - Donner, Handboek wan het Nederlandse staatsrecht, bewerkt door L. Prakke a. zwolle 1989 , (twalfide druk), 179. Dat het in Groot-Brittannie niet anders is gegaan, betoogt Vernon Bogdanor, The Monarchy and the Constitution, Oxford $1995,16-23$.

10 Over de rol van de president bij ontbindingsbesluiten im parlementaire stelsels. Prakke/kortmann. stadtrecht EU passim.

11 Ant 56 van de spanse Crondwet bepaal, onder meet, dat de koning arb:trates and moderates the regular working of the institutions"; art $62 \mathrm{drag}$ de koning op "to summon and dissolve the cortes Generales and to call elections under the terms provided in the Constitution". Kheb de Engelse vertaling van de Sparanse Grondwet gebrukt, die door het Spaanse Ministerie van Algemene Zaken (Presidencia del Gobiemo) is gepubliceerd in 1982. Zle ook: L. Prakke, Het koninkrik Spanje, in: Prakke/Koitmann, Staatsrecht EU, 742. Overigens kent Spanje ook de ontbinding wegens grondwetsherziening, die daar is geregeld zoals in Belgiê: ibidem, 737 .

12 Zie: Jean stengers, De kaningen der Belgen, van Leopold I tot Albert II, Leuven 1997.77 - 90. (Vertaling wan. LAction du Roi en Belgique, Powwoir et Influence.) De eigen beslissingsiruimte van de koning, tot 1940 nog withwel volledig, is na de Tweede Wereldoorlog volgens Stengers sterk gereduceerd. De grondwetsherziening van 1993, die behalve de federalisering ook de constructieve motie van wantrouwen introduceerde, heeft de toepassing van het ontbindings. recht een stuk ingewikkelder gemaakt. Zle daarvoor: Rober Senelle e.a.. Handboek voor de Koning. Tielt 2004, $162-169$. Voor de Deense situatie: IC. Steenbeek en PC. Gllhulis, Het koninkrijk Denemarken, in Prakke/Kortmann, Staatsrecht EU.86-87.

13 Voor de opvattingen van Dicey (1915), en Jennings (1937) zhe: PJ. Oud, Het constitutioneel recht van het Koninkrijk der Nederianden, deel 1, Zwolle 1947,626. 629. Oud verwijst in het bijzonder nat het toemmalige standaardwerk wan W. Ivor Jennings, Cabinet Government, Cambridge 1937 en naar A.V. Dicey, introduction to the stwdy of the Law of the Constitution, 8th edition, London 1915. Veel recenter: Bogdamar, Monarchy, $157-162$. (in de betreffende paragraaf gaat het overigens vooral over de problemen wan "hung parliaments".)

14 Tony Benn diende in 1999, ongetwijfeld om zijn politieke "chef" Tony Blair te sarren, een inttatief-wetsvoorstel in om de macht vande Prime Minister te beperken, zonder succes owerigens. Voor hem sprak vanzelf dat het besluit tot ontbinding wan het Lagerhuis tot de persoonllike prerogatieven van de koning behoort. Zie: Peter Hennessy, The Prime Minister: The Office and its Holders since 1945. New Work 2001, 9 .

15. Oud, Constitutioneel recht, 615-647, spreekt uitwoerig over de rol en positie var de koning bij kamerontbinding. Niet toevallig neemt hij de bewoordingen over van de Negenmannen ut 1844 , die in hun initiatiefvoorstel tot (grondige) herziening van de Grondwet spraken van het "koninklijk recht tot ontbinding van de Tweede Kamen". De operatie van 1844 mislukte wellswaar, matar legde mede de grondslag woor de vernieuwing van de Grondwet in 1848. Al in 1844 was Thorbecke bekeerd tot de kamerontbinding. 
76 Bij de algehele herziening wan de Grondwet in 1983 is het artikel over kamerontbinding, hoewel nog steeds een recht van de negering, ondergebracht in het hoofistuk over de 5 taten-General (nu art.64), nitet echt een "logische" plek Te minder, omdat het hier nog steeds gat am een ongeconditioneerd recht wan de regering, zoals door Oud al betoogd in: Het jongste werteden, parlementare geschiedenis wan Nederlond, deel V, 1933-1937 Assen 1968, 16:22; ook door Prakke, Demissionair kabinet en kamerontbinding, NB, 16 april 1977. afl. 16, 401-405. De verplaatsing in de Grondwet werleidde F. van der Burg ar toe een besluit tot kamerontbinding-inderdaad: dat de trekken heeft gekregen van parlementaire "zelfontbinding" (ziet noot 38) - afhankeligk te maken wan parlementaire instemming. F.H. var der Burg. Beantwoording rechts. wrag (121) Staatsrecht, Ars Aequi, 198\%.34. Vis maakt met de opwatting terecht korte metter: Vis, ontbinding. 118 - 119. Zie ook. Th. W van den Berg Stelregels en spelregels in de Nederlandse politiek, (oratie Leiden), Alpheri atan den Rijn $1990_{1} 4-5$ en 15 .

Over de formele en materiele betekenis wan de handtekening van de koning is recentelijk nog gedebatteerd in de Tweede Kamer naar aanleiding van een notitie over het koningschap van het tweede kabinet-kok. Zle: Handelingen TK 2000-2001,9559-9568. Daablj maakte de minister-preshident duidelifk, dat de koning zijn handtekening onder een besllut wan de regering net kan weigeren, mits hem naar behoren gelegenheid is werschaft wooraf wan ziln zienswijze blijk te geven. Nomaliter zal dat geen probleem oproepen, maar bij een besluit tot kamerontbinding kan de tijdsdruk een belangrike belemmering betekenen woor behoorlijke radpleging van de koning. (lets war ik overigens in mijn Leidse oratie niet bij heb stigestaan.j Julst bij cen gewoelig besluit als dat tot kamerontbinding zou de rumbe woor de koning dienen te worden bewaakt, alvorens hij en de minister-president een ontbindingsbe* sluit ondertekenen. Overigens staat ook Vis in zijn boek over het ontbindingsrecht niet stil bij de huidige positie wan de koning.

in 2002 bleek derhalve dat niet alleen tijdsdruk de koningin bedenktijd ontnam, maar ook het feit dat alle fractievoorzitters en, natar valt aan te nemen. de voorzitter wan de Tweede Kamer hadden geadviseerd tot kamerontbin. ding. Wat wil zeggen dat in elk geval alle openbaar gemaakte adviezen in dezelfde richting wezen en andere mogelijke oplossingen van het probleem met de twee ministers van de IPF praktisch onmogelijk maakten. Leest men echter de Algemene Beschouwingeri wan de vice-president ter inleiding op het Jaarkerlog Raod wan state 2002, 24, nawkeurig dan kan daaruit worden afgeield dat zijn advies a an de koningin sterk afweek wan dat der froctiavoorzitter's Ondat zijn advies gewoontegetrow vertrouweligk bleef, kon het polithek geen gewicht in de schaal leggen. De vaag kan wordan gestelid of de advisering alan het hoofd wan de stat in gewallen van een woordracht tot kamerontbinding niet anders moet worden ingericht, zodat de konimg rieer eigen beoordelingsrumte werkrijgt: niet om hem zijn persoonlijke woorkeuren te doen wolgen, maar om te waarborgen dat de regering enigszins welberaden besluiten neemt die niet louter door de poltieke opwinding wan de dag worden beheerst. 
18 Woor ten kine reks llustratieve woorbetlden. Algemene Beschouwingem van de vice-president, H. Tjeenk Whink in Joarverlog 2002 en Jourverslog 2003 van de Rood van State.

19 Het kiestecht was weliswar een war de belangrike onderwerpen maar bepaald ritet het enige van de grondwetsherziening van 188 7. Een witvoerig overzicht biedt. Th. Buys, De Grondwet, deel W. toelichting en witiek wan de wijzigingen in 887 ingevoend, Arrthem 1888 .

20 Oud/Bosmans, Stoatkundige vormgeving 1, 222-223.

21 Over de dekolonisatie, inclusief de relevantie van grondwetsheralening, zijn intussen boekenkasten vol geschewen. voor de parlementaire kant wan de zaak blift nog steeds van belang: Stempels, De porlementaire geschiedenis van het Indonesische wraagstuk, Ansterdam 995 . De herziening van 1948 is van meer rechtstreekse relevartie geweest woor de totstandkoming var het Statuut woor het Koninkrijk. Zlen Gert Oostindiè en Inge Klinkers, Knellende koninkrijksbanden, het Nederlandse dekolonisatiebeleid in de Caraben, 1940 2000, deel $19,40-1954$. Amsterdam 2001.

22 Deze samenvoeging is mogelijk gemakkt door invoering in 1917 van de zog. "ontbinding op termijn", waarbij de dag van ontbinding en die van de verkiezingen aan elkar zijn gebonden. Voordeel daarvan is, dat de Tweede of Cerste Karter niet wekenlang "ron existent" is en dat de normale gang van werken kan worden woortgezet. Nadeel is dat de regering (tot een zeker maximum) naar beliewen kan gaam schuiven met de ontbindingsdag en dus met de verkezingen, zodat het conflict dat an kamerontbinding ten grondslag heeft gelegen nat de achtergrond werdwijnt, respectievelik een discussle over de aard van de grondwetsheriening wordt ondergesneeuwd door alletlei andere issues. In de terminologie van de pacificatiedemacratie: een staalte van "depolitisering". Over de ontbinding op termijn en tevens over de (ten dele profetische) bezwaren daartegen wan A.A. Struijcken: Vis, Ontbinding, so 59.

23 Bij de grondwetsherziening van $1956 \mathrm{ging}$ het onder meer on de uitbreiding van beide kamers der Staten-Generaal tot 150 resp. 75 leden; bij die van 1963 om het elimineren van Nederlands Nieuw Cunea lit de tekst van de Grondwet, om de troonopwolging en om de leeftid van verkiesbaarheid. in 1972 ging het om het inkomen van de koning, een verlaging van de leeftijd voor actlef kestecht (oorspronkelik een initiatlef wan Ed. wan thin) en nog. cen paar kleingheden. Geen kwesties om de burgers afzonderlijk woor van huis te halen. Belangrijker is de algehele herziening van 1983 (na kamerontbind ing in 1982), on alledde die niet tot de erder gewenste democratiche verneuwingen, 20 als de verklezing van de kubinetsformateur en kamewerkiezingen wolgens een meederheidsstelsel. Zle: JTh.l van den Berg. Tweethonderd Jar grondwetgeving, historie en actualiteit, (Dalderlezing 1998) in: RM Themis, jg. $159,9,299-30$ ?

24. Het toenmalige art 67 in Grw 1953. Voor het belang dararan, onder anderen: E.A. Alkema, Aanzetten voor een nieuwe Nederlandse constitutio na "Maastricht", (thorbeckecollege 20), Antwerpen 1996. 
25 Vergelikk de uitspraak van $H$. baudt in een hnterwew met cerard wan Westerloo, door deze als volgt weergegeven: "Volgens hem [Daudt, Jwde] wordt Nederland in feite geregeerd door een 'regentenklasse' die sterk doet denken aan de Republiek sinds de zeventiende eeuw". Zeker, hast Hans Daudt zich erbil te zeggen, het betreft hier een regentenstelsel met gegarandeerde grondrechten voor ledereen. Maar laten wij het niet met kreten optuigen tot iets dat het niet is een democratie met vertegenwoordigers van het volk". Zie Gerard var Westerloo, Net spreken met de bestuurder, Amsterdam 2003, 245.

26 Over de verambtelijking en "routinisering" van het werk a an de Grondwet: Pelle, In de staatsrechtgeleerde wereld, de politieke geschiedenis wan hoofdstuk 1 wan de Grondwet 1983, Rotterdam 9988,55-92; eerder al het themanummer over de "Proeve wan een nieuwe Grondwe" van Acta Poltica, $2(1966-67)$, in het bijzonder daarin de bijdrage van H. Daudt, Waarom eigenlijk? $135-140$.

27 Daarbij ging het, bij voorbeeld, over afschaffing wan de militaire dienstplicht, de herzieningsprocedure van de Grondwet, zwangerschapswerlof voor volkswertegenwoordigers, deconstitutionalisering van de benoernimg van burgemeesters en commissarissen van de koring en het correctieve wetgevings. referendum. Hier wreekt zich het in Mederland ontbrekende rechterlijk toetsingsrecht aan de Grondwet, waardoor het onmogelijk is om kleinare veranderingen door intelligente grondwetsinterpretatie door te voeren, zodat voor elke kleingheld de Tweede Kamer moet worden ontbonden. Ongelukkig is voorts, dat het op zichzelf prijzenswaardige initiatiefwoorstel van het Tweede-Kamenid, F. Halsema (owerigens na jarenlang gedraal en gezeur aan kabinetskant) tot invoring van zulk toetsingsrecht beperkt blift tot die grondwetsartikelen die handelen ower (klassieke) grondrechten. Voor rechterlijke interpretatie wan andere onderdelen van de Grondwet is Halsema's voorstel dus niet relevant. Ronduit betreurenswaardig is de verwerping, onlangs, door de Tweede Kamer in tweede lezing van het correctieve wetgevingsreferendum. Ware dat well ingevoerd, dan had de herzleningsprocedure van de Grondwet sterk kunnen worden vereenwoudigd, omdat kamerontbinding dan feitelijk overbodig zou zijn geworden. Kiezers hadden dan in voorkomende gevallen bij grondwetsherziening een referendum daarover kunnen verlangen. Maar. Nederlandse politici wertrowwen blijkbaar niemand de koning niet, de rechter niet en wooral de kiezer niet. Vergelibk het houtsnijdende betoog van: $\$.A. Peters, Wie beschermt onize Crondwet?, loratie Amsterdam). Amsterdam 2003.

28 Tweede Kamer $29200 \mathrm{~V} / 1$, no.36: Advies Rad wan State en nader rappont, 4 5 .

29 Dat is overigens nog niet zo eervoudig, omdat veel van wat onze constitutie vormt helemal niet in de Grondwet stat en kennis wan die Crondwet dus ook maar zeer ten dele "helpt". Hoe moellik de zaak ligt, blekk toen de WNG" Uitgeverij een boekje wilde doen verwaardigen met darin de tekst van de Crondwet, eventueel door geneentebesturen aan te bieden ter gelegentheld van in burgering of naturalisatie van migraten. Er moest een inleidende toelichting aan te pas komen on de lezer in de Grondwet enigszins wegwijs te maken en om hem te vertellen dat een hele hoop woor hem belangrîke zaken 
heel ergens anders of zels helemal nergens stadn. Dat zou overgens niet alleen woor miguanten eer problem vormen matr ook voor de meeste Nederlandse statsburgers. Zie: Onze Grondwet, de rechtstat an de grondrechten verklcard voor nieuwe Nederlanders, Den Hagg 2003 ; ook Van den Berg. Tumethonderd jari, 307 .

30 Vis. Ontbinding. 36 .

31 We, ontbinding, 40-44: Van Ralte, Staqtshoofd, 166 - 167. Marcel Werburg. Koningin Emma, regentes van het konihkijk, Baam 1989.923 - 445 en $209-211$.

32 G. Tadi, Liberalen en Radicaten in Nederland, $1872-190$, Den Hag 1980,230 373: Ceorge Harnck e.a. (red), De Antirevolutionalre Farti, 1829 - 1980 , Hiversum 2001,93-112:

33 T. vander Meer e. a, De SDAP en de kiesrechtstrijd, de ontwikkeling wan de sock ad demacratie, 1894 - 1913. Amsterdam 1981.

34. Vis, Ontbinding, $47-48$.

35. Van Welderen Rengers, Schets, deel II, door W.H. Vermeuhen, 68-74. C. de Ru. De stridd over het hoger anderwijs tijdens het ministerie-Kuper Kampen 1953.

36 Oud, Jongste verfeden, $\mathrm{V}, 16-22$.

37 Over leiding en lijdellgkheid in de Nederlandse pacifcatiedemocratie, ditb. zijn Leidse oratie en de tienjarlijkse "vervolgredes": H. Daalder, Van oude en neuwe regenten, politiek in Nederland. Amsterdam 1995; A. Lijphart, verzuling, pocificatie en kentering in de Wederlondse poltiek, Amsterdam 1968 (en vele, al dam niet grondig herziene, vervolgdrukken).

38 Naast de term "parlementaje zelfontbinding" dle licht misverstand kan wekKen ondat aj suggereent dat het intiatief steeds van het parlement zelf utgaat, terwijl het gaat om zelfontbinding van partijcoalities in kabinet en/of parlement, hanteeft Vis ook de term "parlementarisering van het ontbindingsrecht" (elgenlijk een terminologie met hetzelfole "probleem") en wijdter een uitwoerig en boelend hoofdstuk aan in zijn ontbinding. $69-101$.

39 Over Beels interwentie in 1958 uhtwoeriger: lan-Willem Brouwer en Peter van der Helden (red), Parlementaire geschedenis wan Nederland na 1945, deel 6, het kabinet-Drees IV an het kabinet-Beel it, het einde van de rooms-rode coalitie, Den Haag 2004, 275-286 en 293-300. Wrag blift natuurijk was/is voor kamerantbirding een interim *kabinet noodzakelijk of wenselijk? Daarover kan werschiliend worden gedacht, zoals blijkt wit opmerkingen wan Tjeenk Willink in de Agemene Beschouwingen bif het Jaarverslag 2002 Raad van State, dic de "truc" van zijn amblswoorgangel Beel achterafl iets te mooi makt en daartegenover ).J. Vis in thet NJB. 78 (2003). ni 1 (Demissionair en quasl-demissionidir, een pleidoo voor vereenvoudiging).

40 Voor korte maar zeer brukbare feitenowerzichten over de gang van zaken in crisis en formatie tussen 1946 en 2002: C.C.van Baalen, Een rituele dans in de Twe de Kamer klogen over kabinetsfomaties, 1946 - $2002_{3}$ (oratle Nijmegen). Den Halg 2003 , billage $1,27-53$.

4. Meer dan hoop was er trauwens met, hetgeen in de WD tot interne onenigheid leidda Zle: Jan Hoedioman, Hans Wiegel en het spel om de macht Utrecht $1993.45-48$ en $65-71$; Willem Drees, Cesplegeld in de tijd de nagelaten autoblografie, Amsterdam 2000, $993 \cdot 203$. 
42 Jouke die Vries, Grondpolitiek en kabinetscrises, Leiden 1989 , n6-143.

43 Deze wordt uitvoerig en adequat bescheven en geanalyseerd door Vis in Ontbinding, 110 117. waarbil duidelik is dat de auctor intellectualis Ed wan Thin is geweest. in de tijd dat deze fatsoensnom druk werd bediscussleerd (and jaren zeventig) zag ik ef bljkbar niets in: JTh. wan den Berg. Partnerwisseling tussentijds, in: NRC-Handelsblod, 30 april 198\%. Vater opgenomen in: idem. "Aan de gelovigen overgeleverd" opstellen over democratie, regering en parlement, Alphen alar den Rijn 1982,144 - 147.

44 Zie echter de in noot 40 genoemde oratle van C C. van Balen.

45 Over de mogelijke variëteit van coalities na werkiezingen vooral: $\mathrm{H}$. Daudt Echte politicologie, opstellen over politicologie, democratie en de Nederlandse politiek, Amsterdam 1995, 395-414 en Iderm, Een pars intermezzo?, in: Frans Becker e.a. (red), Zeven jaar paars, het tweeentwintigste jaorboek woor het democratisch socialisme. Arrsterdam 2001, 35- 52.

46 Over de gebeurtenissen in de Duitse Bondsrepubliek in 1982 en 1983 ILLW. Broeksteeg e.a., De minister-president in vergelikend perspectief, Den Haag $2004,21-22$, ind verwijzing naar het oordeel daarover van het BVertG $(62,1)$ en naar de meer uitwoerige analyse in: Th. Maunz, Grundgesetz, Kommentor, München 2001. Zie voorts : M.C.Burkens en J.A. vari Schagen, De Bondsrepubliek Duitsland, in: Prakke/Kortmann, Staotsrecht EU, 136. "Kamerontbinding" is in Duitsland lang niet zo eenvoudig als in GrootBrittannië, mopperde Willy Brandt aan het einde van zijn glorieuze reis naar Erfurt (toen DDR) op 19 maart 1973, tegen meereizende journalisten. Dit zou een moment zijn geweest, vond hij, om de Bondsdag te ontbinden. Zie: Peter Merseburger, Willy Brandt, 1913 - 1992, Visionär und Realist, München 2002, 604. Vis wijst in zijn Ontbinding. 61, nog op het pleidooi van PJ. Troelstra in 1924 in de Tweede Kamer om kamerontbinding wooraf te doen gaan door foltmulering van een nieuw regeringsprogramma en vorming van een nieuw kabinet. En motie van die strekking werd door de Tweede Kamer prompt afgewezen.

47 Voor de politieke velanderingen in Nederland, het kiesgedrag in het bijzonder: Hans Daalder and Galen Irwin (ed.). Politics in the Netherlands: How Much Change? London 1989 en, meer recent het themanummer van Acta Politica, vol. 38, Number 1, Spring 2003, in het bijzonder de bijdrage van Huib Pellikaan e.a. The Road from a Depoliticized to a Centrifugal Democracy, $23-49$.

48 Voor een analyse. meer in termen van volatilteit die natuurlik nilet onthend kan worden Bram Peper, Een dolend land, over de politieke architectur wam Nederland Amsterdam 2002, dat overgens ower nog heel wat meer gadt dan alleen het kiesgedrag.

49 Dit pleidooi is niet nieuw: het stond eerder al cential in de fraale analyse van de toenmalige Nederlandse politiek door Ed, wan Thiln. Van partijen naar stembusaccoonden. In: E. Jurgens e.a. Open brief. Partifvernieuwing. Amsterdam 1967,68-73. Zie ook: Th. I. van den Berg. Heeft wan Thijn dan toch gelijk gehads, in: Sachalisme en Democratie, 48 (1991), 361-367, al was het maar om duidelijk te maken dat dit pleidooi ook voor migelf niet nieuw is. 
so Deze "verlelding" roept associates op met een opmerking van thorbecke in een brief adn zign vrouw in de periode dat hij met regelmat naar zijn Limburge wrienden, meestal voor een week achter elkaar, op bezoek moes: "Men eet en drinkt hier, gelik in de romans van Watter Scott onophoudelijk." Datarom juist, , zou lk denken. Zie Lemmens, Worst en Vadertond, 191. 
